\title{
ДОСЛІДЖЕННЯ ВПЛИВУ ПАРАМЕТРІВ ПОДАВАННЯ ІМПУЛЬСНОЇ ВИСОКОЧАСТОТНОЇ НАПРУГИ НА ЗМІНУ ДІЕЛЕКТРИЧНОЇ ХАРАКТЕРИСТИКИ БІОЛОГІЧНИХ ТКАНИН У МОДЕЛІ ЕЛЕКТРОЗВАРНОГО МІЖКІШКОВОГО АНАСТОМОЗУ
}

\author{
С. С. Подпрятов ${ }^{1,2}$, Г. С. Маринський ${ }^{3}$, О. В. Чернець ${ }^{3}$, \\ В. А. Ткаченко ${ }^{3}$, Д. А. Грабовський ${ }^{3}$, \\ К. Г. Лопаткіна ${ }^{3}$, В. А. Васильченко ${ }^{3}$ \\ ${ }^{1}$ Київський міський центр електрозварювальної хірургії та новітніх хірургічних технологій \\ ${ }^{2}$ Київська міська клінічна лікарня № 1 \\ ${ }^{3}$ Інститут електрозварювання ім. Є. О. Патона НАН України
}

\begin{abstract}
Вступ. Електрозварний спосіб створення міжкишкового анастомозу є новітнім і перспективним для втілення. Параметри оптимального радіочастотного впливу на тканини з метою їх з'єднання суттєво різняться поміж дослідницьких груп.

Мета: дослідити вплив амплітуди напруги високої частоти залежно від способу її подавання в імпульсному режимі на зміну діелектричної властивості тканин стінки кишки в моделі електрозварного міжкишкового анастомозу.

Матеріал і методи. Здійснили 120 проб постійного та зростаючого способів подавання на тканину органокомплексу свині радіочастотної електричної напруги імпульсами тривалістю 0,2 секунди після прикладення тиску від 2,0 Н/мм2 до 3,0 Н/мм2. Тканину складали вдвічі в прототипі інструменту, моделюючи міжкишковий анастомоз.

Результати. При подаванні імпульсів 80 В у 82,5\% спостережень імпеданс тканини різко знижувався на $70 \%$ впродовж першого імпульсу, під час другого - плавно ще на 50\% і в подальшому, після коливання на початку імпульсу, стабільно перебував на низькому рівні. Надалі напруга була підвищена до 120 В, і в 92,5\% досліджень рівень імпедансу так само різко знижувався впродовж першого імпульсу майже на 80\%, але під час другого вже набував загалом стабільної форми. При лінійному підвищенні напруги в імпульсі з 80 В до 120 В досягали покращення електропровідності на другому імпульсі у 87,5\% досліджень, де первинний провал імпедансу на початку імпульсу змінився експоненційним зростанням.

Висновки. Подавання імпульсів високочастотної електричної напруги з амплітудою, яка перевищує критичний рівень для тканини, приводить до стабільного покращення електропровідності стінок кишки між електродами, як заведено, вже починаючи з другого імпульсу. Отримані дані є базою для встановлення параметрів алгоритму, спрямованого на гомогенізацію електричних характеристик в місці створення міжкишкового анастомозу.

Обговорення. Виявлений за імпульсної подачі напруги ефект зниження імпедансу стінок кишки між електродами та подальше покращення електропровідності $є$ способом забезпечення рівномірності та глибини структурних перетворень в тканині. Зростання імпедансу при зростаючій напрузі може свідчити або за електричну інерційність іонних систем, або за поглиблені перетворення в тканині. Використання імпульсної подачі напруги обмежуватиме нагрівання тканини в наслідок зниження вкладеної потужності.
\end{abstract}

Ключові слова: тканина, кишка, органокомплекс, імпеданс, електрична напруга, імпульс, анастомоз, електрозварювання.

(c) С. С. Подпрятов, Г. С. Маринський, О. В. Чернець, В. А. Ткаченко, Д. А. Грабовський, К. Г. Лопаткіна, В. А. Васильченко 


\title{
RESEARCH ON HIGH-FREQUENCY VOLTAGE IMPULSES PARAMETERS IMPACT FOR BIOLOGICAL TISSUES DIELECTRIC CHARACTERISTICS IN THE ELECTRICALLY WELDED INTESTINAL ANASTOMOSIS MODEL
}

\author{
S. S. Podpriatov ${ }^{1,2}$, G. S. Marinsky ${ }^{3}$, O. V. Chernets ${ }^{3}$, \\ V. A. Tkachenko ${ }^{3}$, D. A. Hrabovsky ${ }^{3}$, \\ K. G. Lopatkina ${ }^{3}$, V. A. Vasylchenko ${ }^{3}$ \\ ${ }^{1}$ Clinical research centre of bonding/welding surgery and new surgical technologies \\ ${ }^{2}$ Kyiv municipal hospital clinic No. 1 \\ ${ }^{3} \mathrm{E}$. O. Paton Electric Welding Institute of National Academy of Science of Ukraine
}

Introduction. The electrical welding method for the intestinal anastomosis creating is new and promising for clinical implementation. The optimal radiofrequency parameters to tissues influence for providing their connection essentially differ between research groups' publications.

Aim: is to investigate the high frequency voltage influence, depending on its amplitude during impulsed mode, to change intestinal walls' dielectric properties in the model of welded intestinal anastomosis.

Material and methods. 120 probes of constant or growing radio-frequency voltage application to tissues from pig organs complex by 0.2 seconds impulses after pressure from $2.0 \mathrm{~N} / \mathrm{mm} 2$ to $3.0 \mathrm{~N} / \mathrm{mm} 2$ have applied. Organ walls doubled simulating an intestinal anastomosis in the instrument prototype.

Results. At $80 \mathrm{~V}$ stable, in $82.5 \%$ probes tissues impedance dropped sharply by $70 \%$ during the first impulse, while the second - smoothly by $50 \%$ additionally, and in next was stable at a low level after fluctuation at the impulse beginning. Subsequently, the voltage was raised to $120 \mathrm{~V}$, and in $92.5 \%$ probes impedance level declined sharply during the first impulse by $80 \%$, while during the second it was already generally stable. With a linear increasing voltage during the impulse from $80 \mathrm{~V}$ to $120 \mathrm{~V}$, the electrical conductivity improved on the second pulse in $87.5 \%$ probes, where the impedance initial failure at the impulse beginning changed with exponential growth.

Conclusions. The high-frequency voltage impulses, having amplitude is exceeded tissue critical level, leads to a stable improvement in electrical conductivity of intestinal walls between the electrodes, becoming already from the second impulse. The obtained data is the basis for establishment of algorithm parameters, aimed at electrical characteristics homogenizing in the site of intestinal weld anastomosis formation.

Discussion. The impedance reducing effect during impulsed voltage supply to intestinal walls, pressed between the electrodes, and further improving the electrical conductivity is a way to ensure the uniform and deep tissue structural transformations. The impedance growth with increasing voltage can be evidenced either by the inertia of ionic systems, or by in-depth tissue transformations. Using the impulse voltage supply will limit tissues overheating as a result of embedded power lowering.

Key words: tissue, intestine, organ complex, impedance, voltage, impulse, anastomosis, electric welding. 


\title{
ИССЛЕДОВАНИЕ ВЛИЯНИЯ ПАРАМЕТРОВ ПОДАЧИ ИМПУЛЬСНОГО ВЫСОКОЧАСТОТНОГО НАПРЯЖЕНИЯ НА ИЗМЕНЕНИЕ ДИЭЛЕКТРИЧЕСКИХ ХАРАКТЕРИСТИК БИОЛОГИЧЕСКИХ ТКАНЕЙ В МОДЕЛИ ЭЛЕКТРОСВАРНОГО МЕЖКИШЕЧНОГО АНАСТОМОЗА
}

\author{
С. С. Подпрятов ${ }^{1,2}$, Г. С. Маринский ${ }^{3}$ А. В. Чернец ${ }^{3}$, \\ В. А. Ткаченко ${ }^{3}$, Д. А. Грабовский ${ }^{3}$, \\ Е. Г. Лопаткина ${ }^{3}$, В. А. Васильченко 3 \\ ${ }^{1}$ Киевский городской центр электросварочной хирургии и новых хирургических технологий \\ ${ }^{2}$ Киевская городская клиническая больница № 1 \\ ${ }^{3}$ Институт электросварки им. Е. О. Патона НАН Украины
}

\begin{abstract}
Введение. Электросварной способ создания межкишечного анастомоза является новым и перспективным для воплощения. Параметры оптимального радиочастотного воздействия на ткани с целью их соединения существенно различаются между исследовательскими группами.

Цель: исследовать влияние амплитуды напряжения высокой частоты в зависимости от способа ее подачи в импульсном режиме на смену диэлектрических свойств тканей стенки кишки в модели электросварного межкишечного анастомоза.

Материал и методы. Осуществили 120 проб постоянного и возрастающего способов подачи на ткань органокомплекса свиньи радиочастотного электрического напряжения импульсами длительностью 0,2 секунды после приложения давления от 2,0 H/мм2 до 3,0 H/мм2. Ткань составляли вдвое в прототипе инструмента, моделируя межкишечный анастомоз.

Результаты. При подаче импульсов 80 В в 82,5\% наблюдений импеданс ткани резко снижался на $70 \%$ в течение первого импульса, во время второго - плавно еще на $50 \%$ и в дальнейшем, после колебания в начале импульса, стабильно находился на низком уровне. В дальнейшем электрическое напряжение было повышено до 120 В, и в 92,5\% исследований уровень импеданса также резко снижался в течение первого импульса на $80 \%$, но во время второго уже приобретал в целом стабильную форму. При линейном повышении напряжения в импульсе с 80 В до 120 В достигали улучшения электропроводности на втором импульсе в 87,5\% исследований, где первичный провал импеданса в начале импульса сменился экспоненциальным ростом.

Выводы. Подача импульсов высокочастотного электрического напряжения с амплитудой, превышающей критический уровень для ткани, приводит к стабильному улучшению электропроводности стенок кишки между электродами, как правило, уже начиная со второго импульса. Полученные данные являются базой для установления параметров алгоритма, направленного на гомогенизацию электрических характеристик в месте создания межкишечного анастомоза.

Обсуждение. Обнаруженный при импульсной подаче напряжения эффрект снижения импеданса стенок кишки между электродами и дальнейшее улучшение электропроводности является способом обеспечения равномерности и глубины структурных преобразований в ткани. Рост импеданса при возрастающем напряжении может свидетельствовать или об электрической инерционности ионных систем, или об углубленных преобразованиях в ткани. Использование импульсной подачи напряжения ограничивает нагрев ткани вследствие снижения вложенной мощности.
\end{abstract}

Ключевые слова: ткань, кишка, органокомплекс, импеданс, электрическое напряжение, импульс, анастомоз, электросварка.

Вступ. Електрозварний спосіб створення міжкишкового анастомозу є новітнім і перспективним для втілення [5]. Технології радіочастотної коагуляції та високочастотного електрозварювання живих біологічних тканин вже застосовують в різних галузях хірургії та визнають потенційно привабливими для створення нових способів хірургічного лікування [6, 7], тому з'єднання стінок кишки виглядає логічною та очікуваною технологією [5]. Створення електрозварного міжкишкового анастомозу потребує комбінаторного дослідження змін, що відбуваються в реальному часі в стінках кишки під впливом електрозварювального високочастотного струму та інших технологічних параметрів, оскільки специфічна морфологічна будова кишок визначає відмінність їхніх фізичних характеристик (щільності, імпедансу тощо) від інших тканин [4]. Параметри оптимального радіочастотного впливу на тканини, що розглядаються для з'єднання, суттєво різняться поміж дослідницьких груп $[1,3]$.

У первинних дослідженнях електрозварних з'єднань стінок кішок з використанням стандартних режимів роботи обладнання авторами була виявлена нерівномірна та недостатня глибина перетворень у тканинах, що свідчить про суттєву 


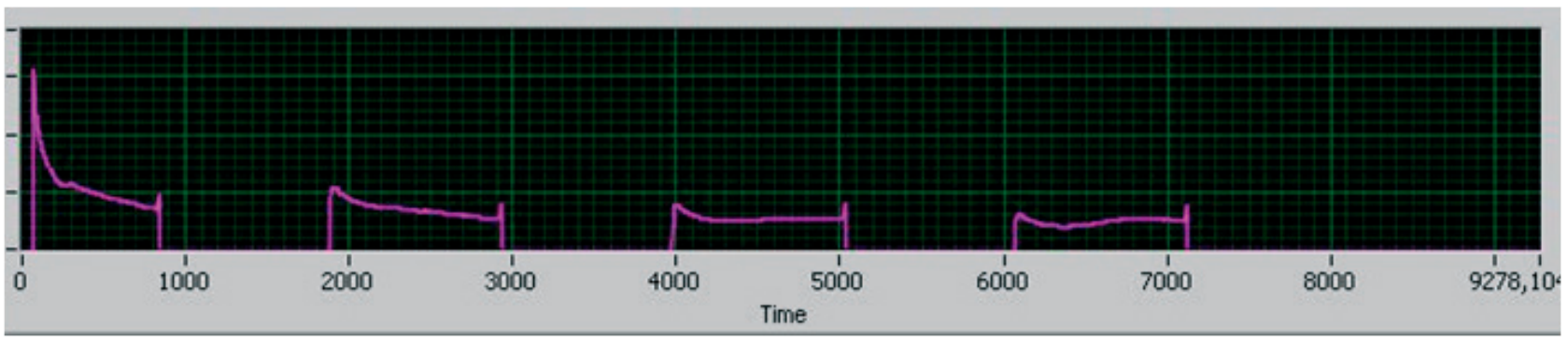

Рис. 1. Зміни електропровідності, відображені у графіку імпедансу стінок тонкої кишки при подаванні імпульсів стабільної напруги 80 В

невідповідність для цього випадку закладених робочих параметрів. У зв’язку з цим авторами було запропоновано ввести стадію «електричної» підготовки тканини до створення з’єднання.

Водночас було встановлено, що безперервна подача високочастотної електричної напруги 20-90 В на стінки кишки протягом 20-60 с приводить лише до нагрівання об’єкту досліджень до температур, що значно перевищують $100^{\circ} \mathrm{C}$ (в умовах експериментів до $\left.125 \pm 5{ }^{\circ} \mathrm{C}\right)$ з відповідною зміною структури тканини зазвичай без надійного зварювання, що не може бути прийнятним.

Обмежити вплив нагрівання за умов досягнення 3’єднання, вочевидь, можливо заміною безперервної подачі напруги на імпульсну, що дозволить зменшити теплову та збільшити чисто електричну складову впливу високочастотного струму.

Мета дослідження: дослідити вплив амплітуди напруги високої частоти залежно від способу її подавання в переривчастому (імпульсному) режимі на зміну діелектричної властивості тканин стінки кишки в моделі електрозварного міжкишкового анастомозу.

Матеріал і методи. В ході експериментів досліджували динаміку змін імпедансу тканин стінки кишки в моделі електрозварного міжкишкового анастомозу людини в залежності від алгоритму подачі високочастотної електричної напруги. Досліджували вплив високочастотної електричної напруги з амплітудою в діапазоні від 80 В до 120 В, постійний та зростаючий способи її подавання на тканину, тривалість одного імпульсу 0,2 секунди, тривалість проміжку між імпульсами 0,2 секунди.

Матеріалом для дослідження був біоімітатор кишки людини з відповідним діаметром та товщиною стінки органу, яким слугував органокомплекс сільськогосподарської тварини - свині. Органокомплекси забирали безпосередньо на фермі після умертвіння тварин, які були заплановані з не пов’язаних з експериментами причин та відбувалися з дотриманням вимог Закону України № 3447-IV «Про захист тварин від жорстокого поводження» та законодавства ЄС. Експерименти проводили в умовах лабораторії відділу електрозварювання живих тканин Інституту електрозварювання ім. Є. О. Патона НАН України.

Об’єкт дослідження охолоджували до $4{ }^{\circ} \mathrm{C}$ та протягом 6-10 годин доставляли до лабораторії. В лабораторії його готували до експерименту, занурюючи у теплий (26-32 $\left.{ }^{\circ} \mathrm{C}\right)$ розчин 0,9\% $\mathrm{NaCl}$ на 10-20 хв, до досягнення тканиною температури розчину [2]. Температуру тканини та розчину вимірювали інфрачервоним безконтактним пірометром GM300 (Benetech).

Використовували розроблений в Інституті електрозварювання експериментальний електрозварювальний стенд з електродною частиною - прототипом клінічного інструменту для міжкішкового анастомозу.

Біоімітатор складали вдвічі, серозними оболонками до середини, моделюючи розташування кишки в циркулярному анастомозі, та фіксували між електродами експериментального стенду.

У 120 дослідженнях прикладали попередньо відкаліброване навантаження ззовні до електродів, створюючи ними тиск на тканину, величину якого

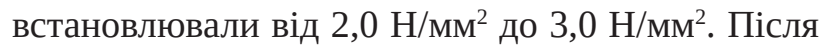
попереднього стиснення подавали електричну напругу на електроди. Показники тиску, тривалість стиснення та наведені вище базові електричні параметри імпульсів були встановлені нами в попередніх дослідженнях.

Як джерело високочастотного електричного струму використовували адаптований до умов експерименту апарат ЕКВ3-300 «Патонмед» (базова робоча частота 440 кГц) конструкції та виробництва Інституту електрозварювання, дозволений до клінічного використання.

Реєстрацію значень струму і напруги в процесі експериментів та моніторинг процесу з виведенням 


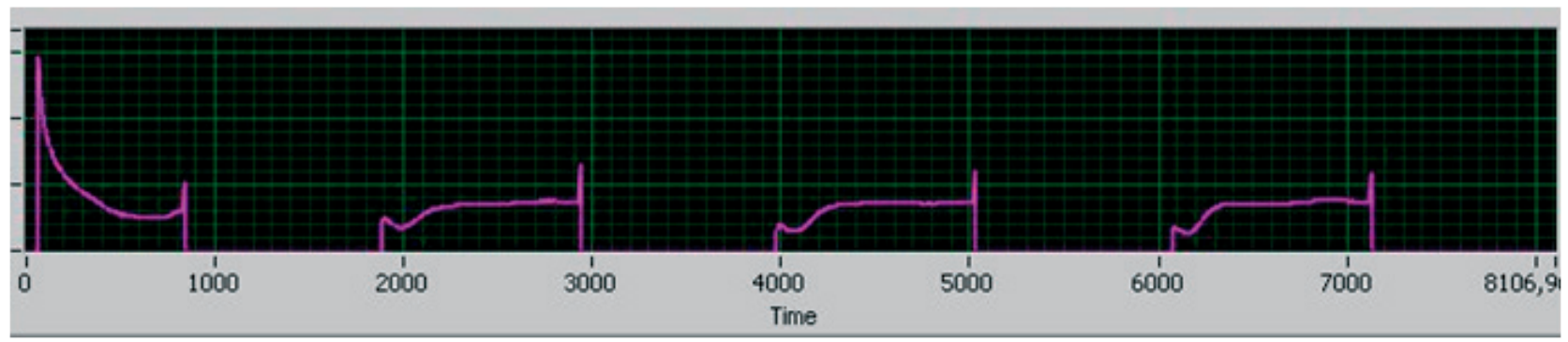

Рис. 2. Зміни електропровідності, відображені у графіку імпедансу стінок тонкої кишки при подаванні імпульсів стабільної напруги 120 В

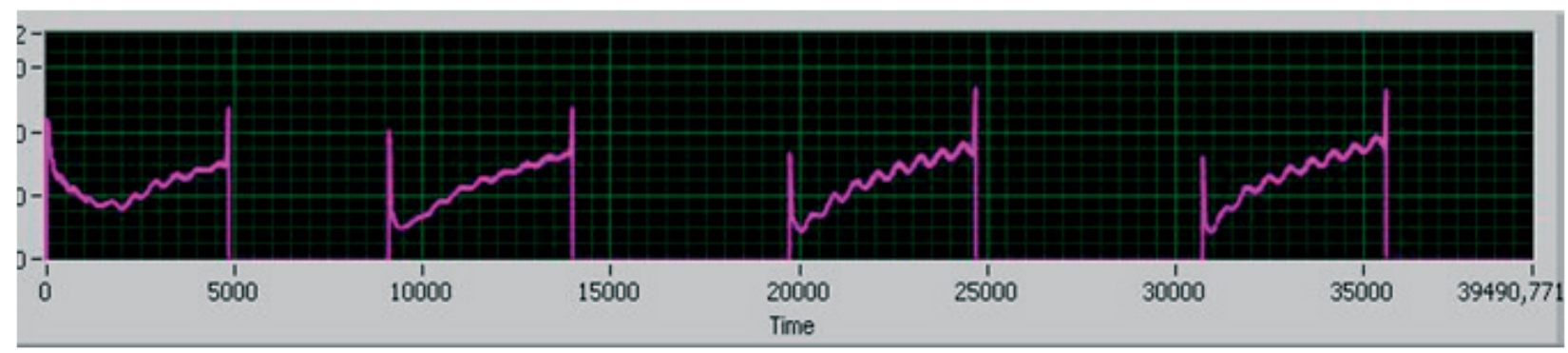

Рис. 3. Характер зміни імпедансу тканини під час подання імпульсів зі зростаючою амплітудою напруги від 80 В до 120 В

на екран в реальному часі цих значень, а також імпедансу та вкладеної в тканину потужності виконували за допомогою модуля швидкого аналого-цифрового перетворення та персонального комп’ютера.

Статистичну обробку отриманих даних виконували з використанням комп’ютерних програм пакету STATISTICA (StatSoft Statistica v.10.0.). Статистичну значимість порівнюваних показників з нормальним розподілом, яка визначалася за критерієм згоди Колмогорова - Смирнова, встановлювали з використанням дисперсійного аналізу (ANOVA) та t-крітерію Ст’юдента, при рівні значущості $\mathrm{p}=0,05$. У тексті наведено репрезентативні фрагменти отриманих даних, представлені як «середнє \pm стандартне відхилення» $(\mathrm{M} \pm \mathrm{s})$.

Результати та їх обговорення. У перших дослідженнях дослідили зміну електропровідності стінок кишки при подаванні на тканини стінок тонкої кишки імпульсів з амплітудою електричної напруги 80 В, визначеною раніше як порогова для настання різкої зміни електричних параметрів тканини (критична напруга).

У 82,5\% досліджень під час першого та другого імпульсів сила струму лінійно зростала впродовж імпульсу, а з третього - стабілізувалася. В решті 17,5\% такий перехід відбувався на третьому або четвертому імпульсі. При цьому імпеданс різко знижувався майже на 70\% впродовж першого імпульсу, далі під час другого плавно ще на 50\% і надалі, після невеликого первинного коливання на початку імпульсу, стабільно перебував на низькому рівні, що свідчило про підвищену електропровідність (рис. 1).

У наступній серії досліджень амплітуда електричної напруги в імпульсах була підвищена до $120 \mathrm{~B}$.

У 92,5\% досліджень сила струму мала лінійно зростаючий профіль лише під час першого імпульсу, в кінці якого відбувався початок переходу на зниження. В наступних імпульсах відбувався лише первинний сплеск сили струму, коротший, аніж в попередньому дослідженні. Після сплеску сила струму була стабільною. В решті 7,5\% спостережень така стабілізація форми відбувалася 3 третього імпульсу. Рівень імпедансу так само різко знижувався впродовж першого імпульсу майже на 80\%, а під час другого вже набував загалом стабільної форми. При цьому, на відміну від попереднього дослідження, початок подавання імпульсу характеризувався миттєвим зниженням імпедансу, а надалі він вже перебував на відносно вищому рівні від попередньо спостереженого (рис. 2).

У спробі зменшити вкладення енергії в тканину, в подальшій серії досліджень лінійно підвищували амплітуду електричної напруги в імпульсі з 80 В до 120 В. 
У цих дослідженнях досягали стабілізації електропровідності на другому імпульсі у 87,5\% досліджень, у $10 \%$ - на третьому, і в 2,5\%- на четвертому. Профіль імпедансу в першому імпульсі мав вигляд проміжного між попередніми двома спостереженими. Лінійне проходження точки мінімуму спостерігали лише під час першого імпульсу, а починаючи з другого первинний пік падіння на початку імпульсу змінювався експоненційним зростанням. Однак, враховуючи амплітуду зміни імпедансу в попередніх дослідженнях, його можна назвати стабільно зростаючим (рис. 3).

Отже, вплив імпульсами напруги, що дорівнює або перевищує критичну для стінок кишки в електрозварному анастомозі, вже після 2-3 імпульсів по 0,2 с викликає різку зміну та подальшу стабілізацію електропровідності тканини на рівні, який значно відрізняється як від первинного, так і від зареєстрованого при тривалому подаванні напруги з амплітудою, нижчою за критичну для даного виду тканин. При цьому зростаючий характер електричної напруги в імпульсі забезпечує нижчу кількість вкладеної в тканини енергії.

Ефект покращення електропровідності спостерігався в усіх дослідженнях. Відхилення в кількості необхідних для цього імпульсів: у дослідженнях 3 високою амплітудою імпульсів - 7,5-12,5 \% спостережень, за нижчої амплітуди (у 17,5\%) співпадало з загрубілістю біоімітатора. Це дає підстави орієнтуватись на більш стабільну прояву цього ефекту в клінічних умовах та визначає необхідність перевірити відпрацьовані режими електрозварювання в передклінічному експерименті.

\section{Висновки.}

1. Подавання на стінки кишки у міжкишковому анастомозі імпульсів високочастотної електричної напруги з амплітудою, що перевищує критичний рівень для цієї тканини, приводить до стабільного покращення електропровідності тканин між електродами, як водиться, вже починаючи з другого імпульсу.

2. Отримані дані $є$ базою для встановлення параметрів першої фази електрозварювального алгоритму створення міжкишкового анастомозу, спрямованої на покращення та гомогенізацію електричних характеристик у місці з’єднання тканин.

Обговорення та перспективи подальших досліджень. Виявлений у дослідженнях ефект зниження імпедансу тканин стінки кишки між електродами та його певна стабільність при умові імпульсної подачі напруги повинні забезпечувати рівномірність та глибину структурних перетворень в тканині, які формуватимуться впродовж повної тривалості електрозварного впливу. Початок та глибину таких перетворень слід вивчити у співставленні змін електропровідності під впливом оптимальної форми імпульсів та морфологічної характеристики тканини. Зростання імпедансу при зростаючій напрузі може свідчити або про електричну інерційність іонних систем, або про поглиблені перетворення в тканині.

3 огляду на встановлену нами раніше відсутність позитивного впливу на електропровідність значного нагрівання тканин електричним струмом 3 постійною подачею напруги, в подальших дослідженнях слід віддавати перевагу використанню імпульсної подачі напруги, що обмежуватиме потужність, вкладену в тканину, та відповідне нагрівання.

\section{Література.}

1. Встановлення первинних вимог до експериментальних засобів дослідження та умов створення електрозварного з'єднання стінок кишечнику / С. С. Подпрятов, С. Є. Подпрятов, А. В. Макаров [та ін.] // Шпитальна хірургія. Журнал імені Л. Я. Ковальчука. — 2018. — № 2. — С. 56-60.

2. Кишечный шов. Физико-механические аспекты / В. И. Егоров, Р. А. Турусов, И. А. Счастливцев, А. О. Баранов. - Москва : Видар, 2004. — 200 с.

3. Bipolar radiofrequency-induced thermofusion of intestinal anastomoses - feasibility of a new anastomosis technique in porcine and rat colon / C. Holmer, H. Winter, M. Kröger [et al.] // Langenbecks Arch. Surg. — 2011. — Vol. 396, No. 4. — P. 529-533.

4. Electrical impedance spectroscopy study of biological tissues / D. A. Dean, T. Ramanathan, D. Machado, R. Sundararajan //. Journal of Electrostatics. - 2008. -Vol. 66, No. 3-4. - P. 165-177.

5. Ho Y. H. Techniques for colorectal anastomosis / Y. H. Ho, M. A. T. Ashour // World J. Gastroenterol. 2010. - Vol. 16, No. 13. - P. 1610-1621.

6. Linchevskyy O. Lung sealing using the tissuewelding technology in spontaneous pneumothorax / O. Linchevskyy, A. Makarov, V. Hetman // European Journal of Cardiothoracic Surgery. — 2010. — Vol. 37. - P. 1126-1128.

7. Radiofrequency vessel-sealing system versus the clamp-crushing technique in liver transection: results of a prospective randomized study on 100 consecutive patients / A. Muratore, A. Mellano, G. Tarantino [et al.] // HPB: The Official Journal of the International Hepato 
Pancreato Biliary Association. - 2014. - Vol. 16, No. 8. - P. 707-712.

\section{References.}

1. Egorov, V. I., Turusov, R. A., Schastlivtsev, I. A., Baranov, A. O. (2004). Kishechnyi shov. Fizikomekhanicheskie aspekty. [Intestinal suture. Physical and mechanical aspects]. Vidar, Moscow. [In Russian].

2. Podpriatov, S. S., Podpryatov, S. E., Makarov, A. V., Marinsky, G. S., Tkachenko, V. A., Chernets, O. V., Tarnavsky, D. V., \& Lopatkina, K. G. (2018). Vstanovlennya pervinnikh vimog do eksperimental'nikh zasobiv doslidzhennya ta umov stvorennya elektrozvarnogo z'ednannya stinok kishechniku [Establishing the first requirements in experimental equipment for investigations and creation conditions of electric welding intestinal connection]. Shpital'na khirurgiya. Zhurnal imeni L. Ya. Koval'chuka (Hospital Surgery. Journal named by L. Ya. Kovalchuk), 2, 56-60. [In Ukrainian]. doi 10.11603/2414-4533.2018.2.9230.

3. Holmer, C., Winter, H., Kröger, M., Nagel, A., Jaenicke, A., Lauster, R., ... Ritz, J. P. (2011). Bipolar radiofrequencyinduced thermofusion of intestinal anastomoses feasibility of a new anastomosis technique in porcine and rat colon. Langenbecks Arch. Surg., 396(4), 529-533. doi: 10.1007/s00423-011-0756-0.
4. Dean, D. A., Ramanathan, T., Machado, D., \& Sundararajan, R. (2008). Electrical impedance spectroscopy study of biological tissues. Journal of Electrostatics, 66(3-4), 165-177. doi:10.1016/j. elstat.2007.11.005.

5. Ho, Y. H., \& Ashour, M. A. T. (2010). Techniques for colorectal anastomosis. World J. Gastroenterol., 16(13), 1610-1621. doi: 10.3748/wjg.v16.i13.1610.

6. Linchevskyy, O., Makarov, A., \& Hetman, V. (2010). Lung sealing using the tissue-welding technology in spontaneous pneumothorax. European Journal of Cardiothoracic Surgery, 37, 1126-1128 DOI: 10.1016/j. ejcts.2009.11.01.

7. Muratore, A., Mellano, A., Tarantino, G., Marsanic, P., De Simone, M., \& Di Benedetto, F. (2014). Radiofrequency vessel-sealing system versus the clamp-crushing technique in liver transection: results of a prospective randomized study on 100 consecutive patients. HPB: The Official Journal of the International Hepato Pancreato Biliary Association., 16(8), 707-712. doi:10.1111/hpb.12207. 